\title{
Social Distinctions in Contemporary Russia: Waiting for the Middle Class Society?
}

Jouko Nikula \& Mikhail Chernysh (red.)

London/New York: Routledge 2020

218 sider. ISBN 9780367465285

Omtalt av Aadne Aasland [seniorforsker, By- og regionforskningsinstituttet NIBR, OsloMet - storbyuniversitetet, aadnea@oslomet.no]

Da jeg som nyansatt forsker på begynnelsen av 1990-tallet skulle være med på å gjennomføre en levekårsundersøkelse etter nordisk modell i utvalgte russiske regioner, fikk jeg hakeslepp da en representant for våre samarbeidspartnere i Moskva ga uttrykk for at det ikke ville være noe poeng å måle andelen fattige, fordi svaret uansett tid og sted alltid er konstant, nemlig $20 \%$. Dette er heldigvis langt fra utgangspunktet til Jouko Nikula og Mikhail Chernysh, som i boka Social Distinctions in Contemporary Russia går løs på den vanskelige oppgaven det er å måle, analysere og forklare sosial stratifisering over tid i et så stort og sammensatt land som Russland. Redaktørene har sammen med bidragsytere fra flere finske (Aleksanteri-instituttet og andre enheter ved Universitetet i Helsinki, Universitetet i Tampere samt Kela/Fpa «Folkpensionsanstalten») og russiske institusjoner studert den sosiale stratifiseringen i Russland på områder som arbeidsliv, sosial mobilitet, boligforhold samt holdninger og verdier. Den empiriske analysen baserer seg i stor grad på datamateriale samlet inn gjennom tre landsdekkende spørreundersøkelser ("The Social Distinctions in Modern Russia Surveys») gjennomført henholdsvis i 1998, 2007 og 2015 gjennom et samarbeid mellom universitetene i Helsinki og Tampere.

Nå er det ikke først og fremst fattigdommen i Russland boka har søkelyset rettet mot, selv om den er innom temaer som framveksten av et russisk prekariat samt utviklingen av inntektsfattigdom og subjektivt opplevd fattigdom. Undertittelen på boka - Waiting for the Middle Class Society? - angir bokas hovedfokus: det er særlig den framvoksende middelklassens posisjon som blir vektlagt i de enkelte tematiske kapitlene. Det er imidlertid ikke opplagt hvem som kan sies å tilhøre den russiske middelklassen; i forskningslitteraturen er både inntekt, materielle levekår, utdanningsnivå og yrkesstatus blitt trukket fram som viktige indikatorer, og disse er slett ikke alltid sammenfallende. 
$\AA$ diskutere sosial ulikhet i Russland med utgangspunkt i middelklassens utvikling og posisjon er et interessant grep. Russiske myndigheter har hatt et ambivalent forhold til den russiske middelklassen. I sine første perioder som president på begynnelsen av 2000-tallet var Vladimir Putin opptatt av å skape en bredere middelklasse som skulle bli det viktigste bidraget til å utvikle det russiske samfunnet. Da denne gryende middelklassen etter hvert stilte større krav til forandring og mer åpenhet, som kulminerte i store protestbevegelser etter påstått valgfusk under presidentvalget i 2012, ble regimets forhold til middelklassen mer anstrengt. Putin har etter dette vært mer opptatt av å sikre oppslutning fra arbeiderklassen og andre tradisjonelle deler av det russiske samfunnet, mens støtten til Putin fra middelklassen, særlig i de store byene, tilsvarende har vært synkende. Samtidig er Putin fortsatt opptatt av at middelklassens status og inntekter må heves for å styrke den russiske økonomien (se for eksempel intervju med TASS i mars 2020). ${ }^{1}$

Nikula og Chernish, samt Markku Kivinen, tar i teoretisk anlagte innledningskapitler utgangspunkt i tidligere utviklet klasseteori, og argumenterer godt for hvorfor denne - til tross for spesifikke russiske forhold som kompliserer slik klasseanalyse også er relevant når man skal studere sosial ulikhet i Russland. Analysen leder fram mot en operasjonell definisjon av middelklassen som tar utgangspunkt i en kombinasjon av yrkesstatus (der hovedvekten legges på graden av autonomi i utøvelsen av yrket) og utdanningsnivå. Slik blir respondentene i spørreundersøkelsene inndelt i tre kategorier (foruten de som er utenfor arbeidsmarkedet): kjernen av middelklassen ("the core of the middle class»), utkanten av middelklassen ("the margins of the middle class») og arbeiderklassen. Begge de to middelklassekategoriene har høyere utdanning, men på grunn av mindre autonomi i yrket befinner de sistnevnte seg i en mellomposisjon mellom kjernemiddelklassen og arbeiderklassen.

Selv om den operasjonelle definisjonen av middelklassen som blir brukt i flere av bokas tematiske kapitler gir analytisk mening, har den som oftest begrenset forklaringskraft når data fra de tre spørreundersøkelsene skal analyseres. Noen ganger er dette et interessant funn i seg selv. Det er for eksempel påfallende i hvor liten grad oppslutningen om statens ansvar for å gi innbyggerne velferd varierer mellom samfunnsklasser; den er jevnt over svært høy. Flere av forfatterne bruker multivariate analyseteknikker, og slik får de fram blant annet hvordan sosiodemografiske kjennetegn som kjønn, alder, grad av urbanitet og levekår spiller sammen med klasse. I andre kapitler, som kun ser på bivariate sammenhenger, kan jeg savne at de går mer i dybden i å utforske hva som forklarer de ulike utfallene, og særlig i tilfeller der sosial klasse har liten forklaringskraft.

De enkelte kapitlene starter gjerne med en litteraturgjennomgang med diskusjon både av begreper og tidligere forskning. Her gis viktige innsikter som plasserer de senere empiriske funnene innenfor relevante rammeverk. Både de finske og de

${ }^{1} \mathrm{https}: / /$ www.youtube.com/watch?v=2mRM5Dbpqww 
russiske forfatterne orienterer seg bredt innenfor både vestlig og russisk litteratur på feltene de skriver om. Selv om kapitlene henter data fra de samme undersøkelsene, er forfatterne tilsynelatende gitt stor grad av frihet i valg av teoretiske rammeverk, samt til å benytte seg av supplerende datamateriale der dette er ansett hensiktsmessig. Dette gjør det noen ganger litt mer krevende for leseren, som må starte «på nytt» for hvert kapittel. Boka blir mindre enhetlig, og det fører til en del gjentakelser. Samtidig gjør det at man får utbytte av å lese de enkelte kapitlene uten nødvendigvis å ha lest de foregående delene først.

I innledningskapitlet får vi en nyttig gjennomgang av den sosiale og økonomiske situasjonen på tidspunktet for gjennomføringen av hver av de tre spørreundersøkelsene. Dette giør det enklere å plassere resultatene innenfor den aktuelle sosiopolitiske konteksten. Jeg har ingen grunn til å betvile kvaliteten på undersøkelsene. Men jeg stusser over at det er såpass lite informasjon i boka om både data og metode. For eksempel mangler viktige opplysninger om svarprosent og frafallsanalyse, informasjon om representativitet av ulike grupper og regioner, samt om eventuell vekting av dataene. En bedre beskrivelse av dataene og et appendiks med spørsmålsformuleringer og svarkategorier i spørreskjemaene hadde også gjort det enklere å ta stilling til de mange, og ikke opplagte, valgene forskerne nødvendigvis har tatt $i$ analysen.

Boka har også en del «skjønnhetsfeil» som gjør at en lurer på om redaktører, fagfeller og forlag har gjort et grundig nok arbeid i å kvalitetssikre de enkelte kapitlene. I et (sannsynligvis) oversatt kapittel brukes for eksempel «relevance» i stedet for "significance» når man refererer til signifikanstester (s. 193-194), det henvises i teksten til tabeller som ikke blir presentert (s. 138), "others» og «total» blandes sammen i en tabell (s. 46), og Aleksej Kudrin blir omtalt som tidligere økonomi-, og ikke finansminister (s. 3).

Men dette blir småplukk i en bok som med sitt fokus på middelklassen er et viktig tilskudd til den allerede omfattende litteraturen om sosial stratifisering i Russland. Den vil utvilsomt være av interesse både for de som er opptatt av å forstå hvordan dynamikken mellom ulike samfunnsklasser i Russland endrer seg, men også for de som med utgangspunkt i komparativ klasseanalyse er interessert i Russland som et spesielt case. 